\title{
Pooled Analysis of 2,408 Cases of Acute Adult Purulent Meningitis from Turkey
}

\author{
Bilgin Arda Oguz Resat Sipahi Sabri Atalay Sercan Ulusoy \\ Department of Infectious Diseases and Clinical Microbiology, Ege University Faculty of Medicine, Bornova, \\ Izmir, Turkey
}

\section{Key Words}

Bacterial meningitis, Turkey · Epidemiology · Systematic review $\cdot$ Pooled analysis $\cdot$ Staphylococcus aureus $\cdot$ Mortality

\begin{abstract}
Objectives: The aim of this study was to systematically review the Turkish literature of acute adult purulent meningitis. Materials and Methods: The published series of three national databases and two international databases were searched to perform the review. In addition to the databases, abstracts of congresses held between 1994 and 2003 by the Turkish Clinical Microbiology and Infectious Diseases Association, Turkish Microbiology Association, and the Antibiotic and Chemotherapy Association were searched for reports about acute purulent meningitis. Results: Data for 2,408 patients with a diagnosis of acute purulent meningitis were obtained from 30 reports. In terms of clinical findings, 1,254 of $1,570(79.8 \%)$ had fever $\left(>38^{\circ} \mathrm{C}\right), 1,408$ of $1,595(88.2 \%)$ headache, 1,403 of 1,562 (89.8\%) stiffness of the neck, and 649 of $784(82.7 \%)$ leukocytosis $\left(>10,000 / \mathrm{mm}^{3}\right)$. Cerebrospinal fluid culture yielded a pathogen in 873 of 2,260 (38.6\%) patients. The most common pathogen was Streptococcus pneumoniae, followed by Neisseria meningitidis and Staphylococcus aureus. Overall mortality was 425 of 2,408 (17.6\%). Pathogenspecific mortality was 60 of 202 (29.7\%) for S. pneumoniae and 6 of 100 (6\%) for N. meningitidis. Conclusion: Meningitis is a serious, life-threatening disease. More preventive measures should be sought to further decrease the mortality and morbidity related to acute purulent meningitis.
\end{abstract}

Copyright $\odot 2007$ S. Karger AG, Basel
(C) 2007 S. Karger AG, Basel

1011-7571/08/0171-0076\$24.50/0

Fax +4161306 1234

E-Mail karger@karger.ch

www.karger.com
Accessible online at:

www.karger.com/mpp

\section{Introduction}

Despite developments in antimicrobial agents and intensive care units, meningitis is still associated with significant mortality and morbidity [1-30]. Vaccination has changed the epidemiology of acute purulent meningitis in developed countries [31]. Several studies of epidemiological or clinical features and prognostic factors in adults with bacterial meningitis have been performed; however, nearly all are retrospective and relatively small in size and many are from developed countries. Studies from Turkey are also retrospective and carry the disadvantage of low patient numbers 1-30]. The aim of this study was to systematically review the literature from Turkey for acute adult purulent meningitis between 1990 and 2004 and compare several parameters for series related to 1995 or earlier and 1996 or later.

\section{Methods}

Three national databases (Ulakbim Turkish Medical Literature database, http://www.turkishmedline.com, http://medline. pleksus.com.tr) and two international databases (Index Medicus and Science Citation Index-Expanded) were searched. The Ulakbim Turkish Medical Literature Database was founded by Tubitak (The Scientific and Technologic Council of Turkey) in 1996. The other two national databases (http://www.turkishmedline.com, http://medline.pleksus.com.tr) are private sector databases. Thus, three different databases were consulted in an endeavor to perform a comprehensive search. Key words for national databases were 'menenjit' or 'meninjit' or 'meningitis'. Key words used for Index Medicus and Science Citation Index were 'meningitis and 
Turkey' and 'central nervous system infection and Turkey'. In addition to the published articles extracted by the above-mentioned methods, abstracts of congresses held by the Turkish Clinical Microbiology and Infectious Diseases Association (KLIMIK), Turkish Microbiology Association and Turkish Antibiotic and Chemotherapy Association (ANKEM) between 1994 and 2003 were searched for studies regarding acute purulent meningitis. The congress proceedings from 1990 to 1993 were not available, therefore, abstracts from this period have not been included. For a more comprehensive review, articles cited in references extracted from sources have also been included. All abstracts found either in databases or in congress abstract books were analyzed by two separate investigators. For studies that were both published and presented at congresses, only the form of the article was taken into consideration. In case of presentations from a single study with overlapping periods, the study covering a longer duration was chosen.

The following categories were excluded: (1) articles published before 1990; (2) pediatric series; (3) Brucella spp., fungus or Mycobacterium tuberculosis-associated case reports/series; (4) aseptic meningitis series; (5) chronic meningitis series, and (6) case reports or series with less than 5 patients.

In mixed series, only cases with acute purulent meningitis were included. Statistical comparisons were made by $\chi^{2}$ test; a $p$ value less than 0.05 was considered as significant.

\section{Results}

Data for 2,408 patients with a diagnosis of acute purulent meningitis were obtained from 30 reports (20 published articles and 10 congress abstracts). Of the 20 published articles, 18 were in peer-reviewed medical journals indexed in national databases and two were published in peer-reviewed journals indexed in international databases.

Of 1,633 patients, $1,032(63.1 \%)$ were male. In terms of clinical findings, 1,254 out of 1,570 (79.8\%) presented with fever $\left(>38^{\circ} \mathrm{C}\right), 1,408$ out of 1,595 (88.2\%) headache, 1,403 out of $1,562(89.8 \%)$ stiffness of the neck, 649 out of $784(82.7 \%)$ leukocytosis $\left(>10,000 / \mathrm{mm}^{3}\right), 882$ out of 1,265 $(69.7 \%)$ vomiting or nausea, 796 out of 1,380 (57.6\%) disturbances in consciousness, 126 out of 535 (23.5\%) epileptic attacks, 34 out of 237 (14.3\%) herpes labialis and 71 out of $758(9.3 \%)$ rash.

Cerebrospinal fluid (CSF) culture yielded a pathogen in 873 out of $2,260(38.6 \%)$ of the patients (table 1). Gram stain was reported to be positive in 462 out of 1,256 (36.7\%) cases. The most common pathogen was Streptococcus pneumoniae, followed by Neisseria meningitidis. Interestingly Staphylococcus aureus was the third most common pathogen and Haemophilus influenzae was reported to be isolated in only 2 cases.

Overall mortality was 425 out of 2,408 (17.6\%). Mortality data for CSF culture-positive and -negative patients
Table 1. Distribution of pathogens isolated in the CSF cultures

\begin{tabular}{lc}
\hline Pathogen & Number \\
\hline Streptococcus pneumoniae & 457 \\
Neisseria meningitidis & 251 \\
Staphylococcus aureus & 29 \\
Enterobacteriacea (species not mentioned) & 8 \\
Coagulase-negative staphylococci & 6 \\
Listeria monocytogenes & 6 \\
Acinetobacter baumannii & 5 \\
Escherichia coli & 4 \\
Gram-negative bacilli (species not mentioned) & 4 \\
Klebsiella pneumoniae & 3 \\
Streptococcus pyogenes & 3 \\
Pseudomonas aeruginosa & 3 \\
Haemophilus influenzae & 2 \\
Branhamella catarrhalis & 1 \\
Proteus mirabilis & 1 \\
Enterococcus spp. & 1 \\
\hline Total & 784 \\
\hline
\end{tabular}

In three reports, the specific bacterial yield of the CSF culture is not shown.
Table 2. Frequency of complications and sequelae

\begin{tabular}{lcc}
\hline Parameter & Number & Percent \\
\hline Brain edema & $33 / 285$ & 11.5 \\
Brain abscess & $15 / 279$ & 5.4 \\
Arthritis & $4 / 77$ & 5.2 \\
Paralysis & $15 / 558$ & 2.6 \\
Deafness & $10 / 507$ & 1.9 \\
Aphasia & $4 / 234$ & 1.7 \\
Diplopia & $2 / 93$ & 2.1 \\
Cranial nerve involvement & $50 / 649$ & 7.7 \\
Hydrocephalus & $28 / 434$ & 6.4
\end{tabular}

were available for only 561 patients. Mortality rates were similar, 42 out of 245 (17.1\%) in those with a negative CSF culture and 53 out of $316(16.7 \%)$ in those with a positive CSF culture ( $\mathrm{p}>0.05)$. Pathogen-specific mortality was 60 out of 202 (29.7\%) for S. pneumoniae and 6 out of 100 (6\%) for N. meningitidis. Frequency of complications and sequelae are summarized in table 2.

When series related to 1995 or earlier and after 1995 were compared, $N$. meningitidis-related meningitis decreased significantly whereas CSF culture positivity and S. pneumoniae-related meningitis increased significantly (table 3). 
Table 3. Comparison of several parameters for series related to 1995 or earlier $[1,2,4,6,9,10,11,13,14,16,17,24,28]$ and related to 1996 or later $[3,5,15,20,23,26,27,30]$

\begin{tabular}{llll}
\hline Parameter & Rate & \\
\cline { 2 - 4 } & 1995 or earlier & 1996 or later & $\mathrm{p}$ \\
\hline Mortality & $137 / 980(13.9)$ & $117 / 746(15.7)$ & $>0.05$ \\
CSF culture positivity & $263 / 832(31.6)$ & $302 / 746(40.4)$ & $<0.05$ \\
S. pneumoniae & $112 / 832(13.4)$ & $156 / 618(25.2)$ & $<0.05$ \\
N. meningitidis & $115 / 798(14.4)$ & $59 / 618(9.5)$ & $<0.05$ \\
\hline
\end{tabular}

Comparisons were made by $\chi^{2}$ test.

Figures in parentheses are percentages.

\section{Discussion}

The mortality rate in community-acquired meningitis in published series from developed countries differs by a wide range, depending on the specific organism. Durand et al. [31] reported a mortality rate of $25 \%$ in 296 community-acquired meningitis episodes, whereas Schuchat et al. [32] reported an overall mortality of 13.3 in 248 patients. The overall mortality of $17.6 \%$ accords with data of Durand et al. [31] and Schuchat et al. [32]. Interestingly, the overall mortality of series related to 1995 or earlier and related to 1996 or later was similar. N. meningitidis and S. pneumoniae meningitis-related mortality is also in accordance with the literature $[32,33]$. Ceftriaxone entered the Turkish market in 1988. The possible contribution of this molecule to therapy might have been lessened by relatively low prevalence of high-level penicillin-resistant S. pneumoniae in Turkey [33].

In this systematic review $H$. influenzae was encountered in only two of $783(0.25 \%)$ CSF culture-positive cases. Although exclusion of pediatric cases might also have affected the situation, $0.25 \%$ is very low when compared with data of Durand et al. [31], who reported an $H$. influenzae rate of $4 \%$ in 296 adult community-acquired meningitis episodes. This may be due to the high natural immunity of Turkish people to $H$. influenzae [34], despite the absence of $H$. influenzae type B vaccine in the National Immunization Program. The decrease in N. meningitidis-related meningitis before and after 1995 is probably due to the routine vaccination program conducted by the military 17]. In an earlier report from Turkey [35] in which 295 acute purulent meningitis cases between 1974 and 1986 were reviewed retrospectively, the most common pathogen was $N$. meningitidis $(76.4 \%$ of all cases) and most cases were soldiers on military duty. Ac- cording to the registry of the Turkish Ministry of Health, there were 9,167 cases of $N$. meningitidis-related meningitis between 1993 and 2002. S. pneumoniae and other acute purulent meningitis cases are not routinely registered in Turkey.

The overall CSF culture positivity level ranges between 60 and $80 \%$ in the literature $[31,36]$, and it was $38.6 \%$ in this study. CSF culture positivity and S. pneumoniae-related meningitis was higher in the series related to 1996 or later than in the series related to 1995 or earlier ( 31.6 vs. $40.4 \%, \mathrm{p}<0.05$, table 1). This comparison may be criticized due to heterogeneity in the microbiologic methods, but the only aim of this comparison was to give the sum of the yield of existing methods in pathogen isolation. In four studies, only classical microbiological techniques were used. The percentage of patients diagnosed with automatic and/or classical methods were not detailed in other studies. The relatively low yield of CSF cultures and the increase in CSF culture positivity in the series related to 1996 or later may be attributed to the recently widespread use of more developed culture systems (automatic culture systems etc.) [37].

There is a tendency not to publish bad results in medicine. For this reason, we included unpublished series as well. The mortality rate of published results and results only presented in congresses were similar (data not shown).

In the present study, data from articles published before 1990 were not included since it was not possible to search those articles in the mentioned databases; series of fewer than 5 patients were excluded since patients in these small series would overlap with the articles or congress abstracts. The three most comprehensive national congresses in the field of infectious diseases and clinical microbiology were searched for data of congress abstracts that had not been converted to published articles. We accessed all of the articles that our searches yielded.

An important disadvantage of our study is the heterogeneity of the data. Because of this heterogeneity, the ratios in different variables have different denominators, therefore, we did not analyze the results of different treatment regimens. Although all centers are tertiary care educational hospitals, possible double report of a single patient from two different centers cannot be excluded. In spite of these disadvantages, this is the first pooled analysis on this topic and may provide major clues about the epidemiology of meningitis in Turkey. 


\section{Conclusion}

Despite developments in the quality of care in hospitals and critical care units as well as those in antibiotic therapy, meningitis is still a life-threatening disease. The vectors that make $S$. aureus the third most common pathogen need to be analyzed. In order to identify the epidemiologic changes, it is necessary to create an appropriate national registration system with fewer bureaucratic entities. It is questionable whether or not the existing sanctions may increase the reporting rate. Increased preventive measures should be sought by the medical community to further decrease the mortality and morbidity related to acute purulent meningitis.

\section{References}

1 Ozyurek S, Yayli G, Kazgol N, Selcuk S: A retrospective evaluation of 311 cases of meningitis. J Turk Microbiol Soc 1991;21:29-36.

2 Kaya A, Tasyaran MA, Parlak M, Yilmaz S: Patients with acute bacterial meningitis followed during the last ten years in Infectious Diseases Clinic of Ataturk University. Mikrobiyol Bul 1995;29:250-254.

3 Turker N, Kayhan B, Ayaydin A, Kaya T, Erbay A: Retrospective evaluation of 73 acute bacterial and tuberculous meningitis cases. İzmir Ataturk Egitim Hastanesi Tip Dergisi 2002;40:31-34.

4 Hosoglu S, Ayaz C, Murt F: Evaluation of 40 patients with acute bacterial meningitis. Dicle Tip Bulteni 1991;18:98-104.

5 Celik I, Ozden M, Kilicoglu A, Demirdag K, Kilic SS: Retrospective evaluation of 121 meningitis cases. KLIMIK Dergisi 2003;16: $11-14$.

6 Bitirgen M, Ural O, Erayman İ: An evaluation of meningitis cases hospitalized in the last four years in the Infectious Diseases and Clinical Microbiology Selcuk University. Karadeniz Tip Dergisi 1995;8:40-43.

7 Sunbul N, Esen S, Eroglu C, Barut S, Pekbay A, Leblebicioğlu H: Retrospective evaluation of 130 cases of meningitis. Turk J Infect 1999; 13:303-308.

8 Alp E, Aygen B, Yıldız O, Sumerkan B, Doganay $\mathrm{M}$ : Acute purulent meningitis: analysis of 67 cases. Turk J Infect 2001;15:123-127.

-9 Topcu S, Dokmetas İ, Yalcin AN: Meningococcal meningitis in adults. Mikrobiyol Bul 1990;24:111-119.

10 Yildirmak T, Eroglu M, Bodur H, Alpaut S: Pneumococcal meningitis in adults: evaluation of 24 episodes. Flora 1996;3:188-191.

11 Yalcin AN, Dokmetas İ, Bakir M, Gurun A: Pneumococcal meningitis in adults: retrospective analysis of 34 cases. Turk J Infect 1996;10:29-31.

12 Aygencel SG, Cetinkaya Y, Uzun O, Akova M, Unal S: Bacterial meningitis in adults: a review of 106 episodes. Flora 1998;3:171177.

13 Coskun D, Goktas P, Ozyurek S, Dag Z: Evaluation of prognosis and the factors affecting prognosis in acute purulent, viral and tuberculous meningitis cases. Flora 1997;3:188194.
14 Ural S, Turker M, Coskun NA, Kurultay N, Vardar I, Tosun D: Cases of meningitis associated to the clinic of infectious diseases, the Izmir State Hospital in the 1986-89 period. Turk J Infect 1990;4:411-416.

15 Yilmaz A, Aribas ET: Prognostic factors in tuberculosis, acute bacterial and aseptic meningitis. Turk J Infect 2002;16:285-290.

16 Goktas P, Sarı A, Ceran N, Ozyurek S: Eighteen cases of mortal meningitis. KLIMIK Dergisi 1998;11:99-102.

17 Ulusoy S, Erdem İ, Dirim Ö, Karakartal K, Gunhan C: Acute bacterial meningitis in adults: evaluation of 148 cases. Turk J Infect 1995;9:27-31.

18 Altunay H, Cekli Y, Cavuslu S: Clinical and laboratory findings of cases with central nervous system infection. Program and abstracts of 10th Turk Clin Microbiol and Infect Dis Congr 2001, p 308.

19 Yesilkaya A, Birengel S, Memikoglu KO, Azap A, Albayrak F, Tekeli E: Retrospective evaluation of 20 cases with acute bacterial meningitis. Program and Abstr of 30th Turk Microbiol Congr 2002, p 382.

20 Yamazhan T, Arda B, Tasbakan M, Gokengin D, Ulusoy S, Serter D: Analysis of 94 cases with acute purulent meningitis. KLIMIK Dergisi 2004;17:95-98.

21 Ozer S, Oltan N, Ak O, Yıldırım N, Dereli Y, Kuzu I: Evaluation of 61 acute bacterial meningitis cases. Program and Abstr of 28th Turk Microbiol Congr 1998, pp 20-344.

22 Vardar I, Coskun NA, Kayhan B, Ozer P, Ormen B: Evaluation of bacterial, tuberculous and aseptic meningitis cases. ANKEM Dergisi 1997;2:11.

23 Buzgan T, Irmak H, Karahocagil MK, Sanl B, Akdeniz H, Demiröz AP: Evaluation of 82 bacterial meningitis cases. Program and Abstr of Turk Clin Microbiol and Infect Dis Congr 2001, p 307.

24 Basaran G, Aygun G, Eroglu C, Dirican A, Oztürk R, Bagdatli Y: 128 cases with purulent meningitis. Program and Abstr of 27th Turk Microbiol Congr 1996, p 157.

25 Cagatay A, Kucukoglu S, Gulec L, Berk H, İnce $\mathrm{N}$, Ozsüt $\mathrm{H}$, Eraksoy $\mathrm{H}$, Calangu S: Bacterial meningitis in adults: evaluation of 156 cases. Program and Abstr of Turk Clin Microbiol and Infect Dis Congr 2003, p 285.
26 Baran G, Colpan A, Akinci E, Erbay A, Eren $\mathrm{S}$, Bodur H: Acute meningitis: evaluation of 25 cases. Program and Abstr of Tur Clin Microbiol and Infecti Dis Congr 2003, p 285.

27 Altuntas OA, Kart KY, Gulduren S, Alan MS, Ergin G, Sengoz G, Nazlican O: Retrospective evaluation of 76 cases of acute bacterial meningitis followed up in the last 5 years. Program and Abstracts of Turk Clin Microbiol and Infect Dis Congr 2003, p 285.

28 Dokuzoguz B, Eren S, Erbay A, Baykam N, Alpaut S: Clinical and laboratory evaluation of 94 cases of meningitis. Program and Abstr of Turk Microbiol Congr 1996, p 159.

29 Hosoglu S, Ayaz C, Geyik MF, Kokoglu OF, Ozen A: Acute bacterial meningitis in adults: analysis of 218 episodes. Ir J Med Sci 1997; 166:231-234

30 Celal A, Faruk GM, Salih H, Kemal CM, Serife A, Faruk KO: Characteristics of acute bacterial meningitis in Southeast Turkey. Indian J Med Sci 2004;58:327-333.

31 Durand ML, Calderwood SB, Weber DJ, Miller SI, Southwick FS, Caviness VS, Swartz $\mathrm{MN}$ : Acute bacterial meningitis in adults: a review of 493 episodes. N Engl J Med 1993; 328:21-28.

32 Schuchat A, Robinson K, Wenger JD, Harrison LH, Farley M, Reingold AL, Lefkowitz L, Perkins BA: Bacterial meningitis in the United States in 1995. N Engl J Med 1997;337: 970-976.

33 Sener B: Penicillin resistance in Streptococcus pneumoniae clonal relatedness of resistant pneumococci. Ankem Dergisi 2007; 21(suppl 2):171-177.

-34 Ocaktan E, Ozyurda F, Akar N: Natural immunity to Haemophilus influenzae type B in children of Ankara, Turkey. Pediatr Int 2004; 46:280-284.

35 Karakartal G, Gunhan C, Buke M, Serter D, Yuce K, Karpat H, Tutuncu T: Cases of meningitis in Izmir and vicinity 1974-1986. Turk J Infect 1987;1:1-4.

36 Kaplan SL: Clinical presentations, diagnosis and prognostic factors of bacterial meningitis. Infect Dis Clin North Am 1999;13:579594.

37 Gurler N: Automation in microbiology. Program and Abstracts of 31st Turk Mirobiol Congr 2004, pp 9-10. 